\title{
PENGEMBANGAN BAHAN AJAR MAHARAH QIRA'AH BERBASIS KARAKTER DI PERGURUAN TINGGI
}

\author{
Laily Fitriani
}

Universitas Islam Negeri Malang

E-mail: laily@bsa.uin-malang.ac.id

\begin{abstract}
الملخص

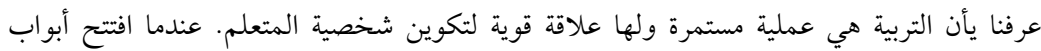

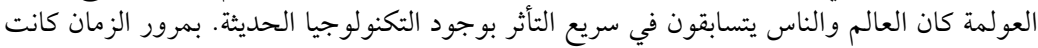

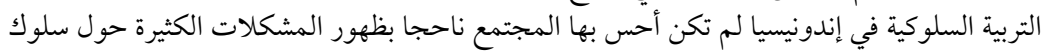

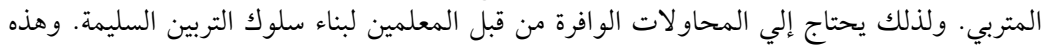

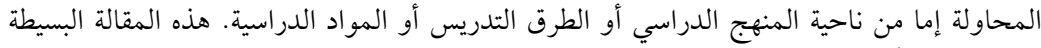

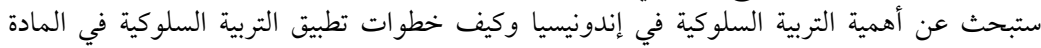

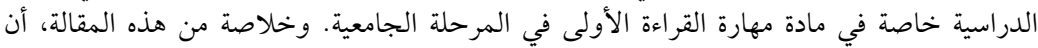

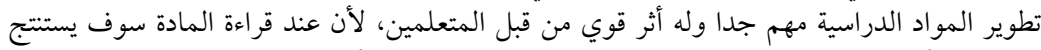

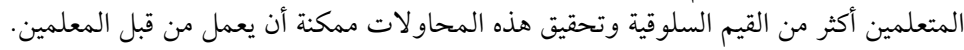

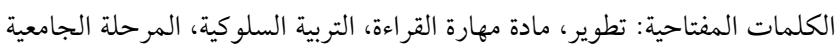

\begin{abstract}
Abstrak
Kita telah tahu bahwa pendidikan adalah kegiatan yang terusmenerus dan memiliki hubungan yang kuat untuk membentuk karakter pembelajar. Ketika pintu globalisasi terbuka maka dunia dan manusia saling berlomba untuk cepat merespon adanya teknologi modern. Seiring dengan berjalannya waktu, pendidikan karakter di Indonesia belum dirasakan berhasil oleh masyarakat seiring munculnya permasalahan-permasalahan seputar perilaku peserta didik. Oleh sebab itu, perlu adanya banyak usaha dari kalangan pengajar untuk membangun perilaku peserta didik. Usaha-
\end{abstract}


usaha ini baik dari segi kurikulum, metode pengajaran atau bahan ajar. Makalah sederhana ini akan membahas tentang pentingnya pendidikan karakter di Indonesia dan bagaimana langkah-langkah praktek pendidikan karakter dalam bahan ajar, khususnya dalam materi Maharah al-Qira'ah 1 pada jenjang universitas. Intisari dari makalah ini bahwa pengembangan bahan ajar sangat penting dan memiliki pengaruh yang kuat di kalangan para pembelahar, sebab ketika membaca materi, para pembelajar akan mendapatkan hasil nilai-nilai pendidikan karakter yang lebih banyak, dan mewujudkan usaha-usaha yang mungkin dilakukan di kalangan para pengajar.

Kata kunci: Pengembangan, Materi Maharah al-Qira'ah, Pendidikan Karakter, Jenjang Universitas.

\section{A. Pendahuluan}

Pendidikan idealnya merupakan sarana humanisasi bagi peserta didik, sebab pendidikan memberikan ruang bagi pengajaran etika moral dan segenap aturan luhur yang membimbing peserta didik mencapai humanisasi. Melalui proses itu, peserta didik menjadi terbimbing, tercerahkan, sementara ketidak tahuannya akan terbuka lebar-lebar untuk menjadi tahu, sehingga mereka dapat mengikis bahkan meniadakan aspekaspek yang mendorong ke arah dehumanisasi. Hal ini yang menyebabkan akan melahirkan sosok manusia sejati yang kaya akan visi hunamisme dalam kerangka kognitif, afektif dan psikomotorik. ${ }^{1}$ Sehingga pendidikan pada hakekatnya tidak hanya mendidik peserta didik untuk menjadi manusia yang cerdas, tetapi juga membangun kepribadian agar berakhlak mulia. Saat ini, Indonesia sedang giat mengembangkan model pendidikan karakter dari tingkat dasar, menengah, hingga ke perguruan tinggi, sebab saat ini pendidikan di Indonesia dinilai kurang berhasil dalam membangun kepribadian peserta didik agar berakhlak mulia. ${ }^{2}$ Sehingga pendidikan karakter dipandang sebagai kebutuhan yang mendesak dan perlu dilaksanakan oleh seluruh masyarakat, baik berada dalam lingkungan pendidikan formal maupun non formal.

Sebagai warga negara Indonesia, pembangunan karakter merupakan perwujudan amanat Pancasila dan UUD 1945 yang dilandasi oleh semangat Pancasila. Sebagaimana dalam Undang-undang No. 20 tahun 2003 2013). h: 1

${ }^{1}$ Agus Wibowo. Pendidikan Karakter Berbasis Sastra. (Yogyakarta: Pustaka Pelajar,

2 Akhmad Muhaimin Azzet. Urgensi Pendidikan Karakter Di Indonesia. Jogjakarta: Ar-Ruzz Media, 2011), h: 15. 
tentang Sistem Pendidikan Nasional telah ditegaskan bahwa Pendidikan Nasional berfungsi mengembangkan kemampuan dan membentuk watak serta peradaban bangsa yang bermartabat dalam rangka mencerdaskan kehidupan bangsa, bertujuan untuk mengembangkan potensi peserta didik agar menjadi manusia yang beriman, bertakwa kepada Tuhan Yang Maha Esa, berakhlak mulia, sehat, berilmu, cakap, kreatif, mandiri, dan menjadi warga negara yang demokratis serta bertanggung jawab. ${ }^{3}$ Akan tetapi seiring berubahnya zaman, upaya yang dilakukan tampaknya masih membutuhkan usaha keras dalam mewujudkan dan menginternalisasikan nilai-nilai pendidikan karakter di kalangan lembaga pendidikan.

Perguruan tinggi sebagai salah satu lembaga pendidikan memiliki tanggung jawab besar pada masyarakat untuk meluruskan arah pendidikan terutama di perguruan tinggi sehingga tidak hanya membangun intelektualitas para mahasiswa melainkan juga mengimbanginya dengan pendidikan moral/akhlak, sehingga diharapkan akan menghasilkan pemimpin-pemimpin yang memiliki kemantapan akidah dan kedalaman spiritual, keluhuran akhlak, keluasan Ilmu dan kematangan profesional. Hal ini adalah merupakan cita-cita besar Indonesia, saat memasuki era global ini diharapkan perguruan tinggi tidak hanya membekali mahasiswanya dengan berbagai keilmuan yang teoritis tetapi juga praktis dan yang terpenting keilmuan-keilmuan tersebut dapat melahirkan mahasiswa yang dapat membawa karakter baik, sehingga dapat membudaya dan menginternal dalam diri para mahasiswa.

Berbicara karakter tentu tidak dapat dilepaskan dari maraknya pemberitaan media tentang rapuhnya karakter anak bangsa. Pendidikan karakter sesungguhnya masih dibutuhkan di Indonesia melalui pengembangan kurikulum sekolah dan universitas, diantaranya melalui pengembangan bahan ajar. Saat ini Indonesia tengah memasuki era pasar bebas, era teknologi canggih dan kesemuanya membutuhkan beragam penyikapan-penyikapan. Dalam konteks pendidikan Indonesia, sesungguhnya gaung pendidikan karakter sudah lama dicanangkan dan diterapkan. Kondisi ini masih sangat relevan dan hingga kini, pendidikan karakter masih diterapkan pada pendidikan dasar, menengah, hingga perguruan tinggi.

${ }^{3}$ Yunus Abidin. Pembelajaran Membaca Berbasis Pendidikan Karakter. (Bandung: PT. Refika Aditma, 2012). H: 29. 
Untuk mengatasi berbagai persoalan dekadensi moral anak bangsa, saat ini pemerintah dan rakyat Indonesia tengah gencar dalam proses mengimplementasikan dan menginternalisasikan nilai-nilai pendidikan karakter dari tingkat dini (PAUD), sekolah dasar (SD/MI), sekolah menengah (SMP/MTs dan SMA/MA) hingga perguruan tinggi. Melalui pendidikan karakter ini, diharapkan dekadensi moral anak bangsa akan teratasi dan selanjutnya akan melahirkan generasi-generasi bangsa berkarakter dan humanis. ${ }^{4}$

Pembelajaran Mahara al-Qiraah di perguruan tinggi masuk dalam kategori membaca pemahaman (Comprehension Skill) dan membaca kritis (Critical Reading), dalam hal ini mahasiswa selain harus memiliki kompetensi mampu membaca teks berbahasa Arab sesuai dengan nahwu shorof, mereka juga mampu memahami isi teks dengan mengkaitkannya dalam kehidupan dirinya dan masyarakat.

Bahan ajar merupakan unsur setelah pengajar dan peserta didik dalam proses belajar mengajar. Dalam konteks hari ini, bahan ajar adalah salah satu faktor penting dalam menjawab permasalahan dekadensi moral anak bangsa dengan memasukkan muatan karakter ke dalam kurikulum perguruan tinggi untuk selanjutnya akan diturunkan dan dijabarkan dalam tataran bahan ajar, sehingga mahasiswa mendapatkan manfaat dari membaca berbagai teks berbahasa Arab yang dipelajarinya.

Berdasarkan persoalan diatas dan analisis kebutuhan tentang pentingnya internalisasikan nilai-nilai pendidikan karakter di kalangan perguruan tinggi, penulis berkeinginan untuk membahas pendidikan karakter dalam kaitannya dengan pembelajaran maharah al-Qiraah di perguruan tinggi, sehingga setelah mahasiswa mempelajari teks membaca diharapkan mereka dapat mengambil nilai-nilai yang terkandung dalam bacaan kemudian berusaha membumikan nilai-nilai tersebut dalam lingkup pribadi dan lingkungannya.

${ }^{4}$ Agus Wibowo. Pendidikan Karakter Berbasis Sastra. (Yogyakarta: Pustaka Pelajar, 2013). h: 10. 


\section{B. Pembahasan}

\section{Pendidikan Karakter di Perguruan Tinggi}

Pendidikan, edukasi berasal dari bahasa Latin, dari akar kata, ex (keluar) dan ducere, duct, duco (memimpin, mengadakan, membangunkan). Edukasi dengan demikian dapat diberikan dua pengertian, yaitu:

1) Membawa ke luar, mengeluarkan kemampuan seseorang, dalam hubungan ini potensi-potensi yang sudah ada, sebagai bakat, mengarahkannya ke tingkat yang lebih maju.

2) Kemampuan yang sudah dicapai bukan semata-mata merupakan milik individual, akan tetapi sebagai makhluk sosial setiap individu menularkannya kepada individu lain, demikian seterusnya, sehingga terjadi mata rantai proses edukasi. Dengan demikian, pendidikan bukanlah proses individu, akan tetapi merupakan proses sosial. ${ }^{5}$

Pendidikan karakter adalah pendidikan budi pekerti plus, yaitu pendidikan yang melibatkan aspek pengetahuan (cognitive), perasaan (feeling) dan tindakan (action) sebagaimana yang telah disampaikan oleh Lickona (dalam Yunus, 2013) bahwasanya seseorang berkarakter jika ia telah menunjukkan tiga ranah besar karakter, yang dijabarkan sebagai berikut:

1) Pengetahuan tentang moral

a. Kesadaran moral, yakni seseorang mengetahui mana yang baik dan mana yang tidak baik.

b. Pengetahuan tentang nilai moral, yaitu seseorang mengetahui tentang beragam jenis nilai moral misalnya jujur, toleran, adil, respek, disiplin, baik hati, responsibilitas, tanggung jawab, mandiri, kerja keras, ingin tahu, dll.

c. Pengambilan prespektif yakni kemampuan seseorang untuk mengambil sudut pandang orang lain sebagaimana orang lain memandang, mengimajinasikan bagaimana mereka berpikir, mereaksi, dan berperasaan.

d. Keberalasan moral yakni pemahaman seseorang tentang mengapa hal itu disebut bermoral, apa sebenarnya moral?

${ }^{5}$ Nyoman Kutha Ratna. Peranan Karya Sastra, Seni dan Budaya Dalam Pendidikan Karakter. Yogyakarta: Pustaka Pelajar. 2014). H: 74. 
e. Pengambilan keputusan, yaitu kemampuan seseorang dalam mengambil sebuah keputusan secara tepat dan bijak.

f. Pemahaman diri, bahwa seseorang harus mampu mengetahui dirinya sendiri untuk meninjau ulang tingkah lakunya dan mengevaluasi berbagai tingkah laku yang menyimpang yang dilakukannya.

2) Perasaan Moral

a. Kesadaran, sadar dalam menentukan sesuatu berdasarkan pengetahuan maupun perasaan.

b. Percaya diri, seseorang dikatakan berkarakter bila memiliki rasa percaya diri dan mandiri.

c. Empati, yakni peduli terhadap sesama atau orang lain.

d. Mencintai yang baik, artinya seseorang berkarakter bila mencintai kebenaran, memperjuangkan kebenaran dan senantiasa berbuat sesuatu yang baik.

e. Kontrol diri, artinya seseorang dikatakan berkarakter jika ia mengontrol dirinya secara emosional.

f. Kerendahan hati, yaitu kemampuan untuk menerima kebenaran dan kemampuan untuk melakukan kegiatan memperbaiki kesalahan yang telah dilakukannya.

3) Aksi Moral

a. Kompetensi, artinya kemampuan yang dimiliki untuk mengaplikasikan keputusan dan perasaan moral ke dalam aksi moral yang dilakukannya.

b. Keinginan, artinya kemampuan seseorang untuk melakukan segala sesuatu yang diinginkan sesuai dengan nilai moral yang berlaku

c. Kebiasaan, yakni kebiasaan untuk melakukan segala sesuatu berbasis kearifan lokal.

Berdasarkan uraian diatas, pendidikan karakter adalah pendidikan yang menitikberatkan pada nilai-nilai karakkter peserta didik, dengan penerapan nilai-nilai karakter nantinya akan membuat para peserta didik memiliki karakter yang baik dan dapat mengembangkannya dalam kehidupan pribadinya dan masyarakat. 


\section{Pengembangan Bahan Ajar}

\section{a. Definisi Bahan Ajar}

Menurut Pannen dalam (Belawati, 2003) bahan ajar adalah bahanbahan atau materi pelajaran yang disusun secara sistematis yang digunakan guru dan siswa dalam proses pembelajaran. ${ }^{6}$ Senada dengan Pannen, Kemp (dalam Muslic) menyebutkan bahwa bahan ajar adalah gabungan antara pengetahuan (fakta dan informasi rinci) dan keterampilan (langkahlangkah, prosedur, keadaan, dan syarat-syarat) dan sikap. ${ }^{7}$

Bahan ajar dapat menjadi instrument yang menunjang keberhasilan sebuah pembelajaran. Sehingga dalam pemuatan bahan ajar diperlukan prinsip-prinsip penyajian materi bahasa Arab yaitu prinsip seleksi, gradasi dan korelasi. Prinsip seleksi yaitu bahan ajar harus menunjukkan pemilihan materi yang memang diperlukan oleh pembelajar di tingkat tertentu. Prinsip gradasi adalah berjenjang dalam hal penyajian bahan ajar yang mudah hingga susah. Korelasi adalah bahwa materi yang disajikan memiliki kaitan yang saling menguatkan dan menjadi panduan yang utuh. ${ }^{8}$

\section{b. Faktor-faktor dalam Pengembangan Bahan Ajar}

Bahan ajar memiliki peran penting dalam proses pembelajaran, yaitu acuan bagi siswa dan guru, bahan ajar menjadi acuan yang diserap isinya dalam proses belajar sehingga dapat menjadi pengetahuan, dan bagi guru atau dosen bahan ajar menjadi acuan paket bahan ajar yang sudah disusun oleh kementerian. Akan tetapi, keberadaan bahan ajar juga membuka ruang bagi guru atau dosen untuk mengembangkannya, apalagi kurikulum pendidikan yang relatif selalu berubah tentu sangat memungkinkan bagi guru atau dosen untuk mengambil bagian ini.

Ada faktor-faktor yang dipertimbangkan bagi guru dan dosen dalam mengembangkan sebuah bahan ajar menurut Belawati ${ }^{9}$, sebagai berikut:

1) Kecermatan Isi

${ }_{6}$ Tian Belawati. Pengembangan Bahan Ajar. (Jakarta: Pusat Penerbitan Universitas Terbuka, 20013). h: 1.3)

7 Masnur, Muslich. Text Book Writing: Dasar-dasar Pemahaman,Penulisan dan Pemakaian Buku Teks. (Jogjakarta:Ar-Ruzz Media). h: 201-219.

${ }^{8}$ Acep Hermawan. Metodologi Pembelajaran bahasa Arab. (Bandung: PT. Remaja Rosdakarya. 2011). H: 106-107

9 Tian, Belawati. h: 2.2-2.14. 
Kecermatan isi adalah validitas atau kesahihan isi atau kebenaran isi secara keilmuan dan keselarasan isi. Validitas yang dimaksud adalah bahwa bahan ajar yang dikembangkan tidak asal-asalan. Isi bahan ajar yang dikembangkan berdasarkan konsep dan teori yang berlaku dalam bidang ilmu serta sesuai dengan perkembangan ilmu pengetahuan, sehingga isi bahan ajar yang dikembangkan dapat dipertanggung jawabkan secara ilmiah.

Keselaran isi dalam bhan ajar berarti kesesuaian isi bahan ajar dengan sistem nilai dan falsafah hidup yang berlaku dalam negara dan masyarakat dimana lembaga itu berada.

2) Ketepatan Cakupan

Ketepatan cakupan berhubungan dengan keluasan dan kedalaman isi atau materi, serta keutuhan konsep berdasarkan bidang ilmu. Pertama dilihat tujuan dari pengembangan bahan ajar yang dimaksud, kemudian berdasarkan tujuan ditentukan seberapa luas, dalam dan utuh topik yang akan disajikan kepada peserta didik.

3) Ketercernaan Bahan Ajar

Ketercernaan Bahan ajar artinya bahan ajar dapat dipahami dan isinya dapat dimengerti oleh siswa dengan mudah. Ada enam hal yang mendukung tingkat ketercernaa bahan ajar, sebagai berikut:

a) Pemaparan yang logis

Artinyabahanajardipaparkansecaralogis,misalnyadimulaidari yang umum ke yang khusus atau sebaliknya, dari yang mudah ke yang sukar, atau dari inti ke pendukung. Dengan demikian, pembelajar akan mudah memahami dan menggunakan bahan ajar dan membantunya untuk mengembangkan pola pikir atau penalaran yang sistematis.

b) Penyajian materi yang runtut

Artinya bahan ajar disajikan secara sistematis, tidak meloncatloncat. Keterkaitan antar materi atau topik dijelaskan secara cermat kemudian setiap topic disajikan secara sistematis dengan strategi penyajian uraian, contoh dan latihan. Keruntutan penyajian isi bahan ajar mempermudah siswa dalam belajar dan juga menuntun siswa untuk terbiasa berpikir runtut.

c) Contoh dan ilustrasi yang memudahkan pemahaman 
Artinya ketika menyajikan topik dan memaparkan suatu pokok bahasan diperlukan contoh dan ilustrasi yang dapat membantu dan mempermudah pemahaman peserta didik.

d) Alat bantu yang memudahkan

Artinya bahan ajar perlu memiliki alat bantu yang dapat mempermudah siswa dalam mempelajari isi bahan ajar yang dikenal dengan Mnemonic Devices (alat bantu mengingat atau belajar), misalnya kotak rangkuman di setiap akhir topik, tanda-tanda dalam bahan ajar, misalnya tanda dalam melaksanakan latihan, tanda untuk menghafal mufradat, dan lain sebagainya.

e) Format yang tertib dan konsisten

Artinyabahanajarperlumemeliharaketertibandankonsistensiagar mudah dikenali, diingat dan dipelajari oleh peserta didik, misalnya warna kertas dibedakan.

a) Penjelasan tentang relevansi dan manfaat bahan ajar

Artinya dalam bahan ajar perlu ada penjelasan tentang manfaat dan kegunaan bahan ajar dalam materi pelajaran atau perkuliahan, sehingga peserta didik dapat melihat keterkaitan antara topik yang dibahas dalam bahan ajar dengan topik-topik lainnya.

4) Penggunaan Bahasa

Penggunaan bahasa menjadi salah satu faktor yang penting dalam mengembangkan bahan ajar. Bahan ajar yang baik diharapkan dapat memotivasi siswa untuk membaca, mengerjakan tugas-tugasnya, serta menimbulkan rasa ingin tahu peserta didik untuk terus mengeksplorasi isi bahan ajar. Senada dengan Mahmud Kamil an-Naqah ${ }^{10}$ bahwa penulisan bahan ajar bahasa Arab menggunakan bahasa Arab fushah, menggunakan bahasa dasar terkait mufradat, menggunakan kaidah gramatikal yang benar, dan menggunakan tanda baca.

5) Perwajahan atau Pengemasan

Perwajahan dan pengemasa berperan penting dalam perancangan atau penataan letak informasi dalam satu halaman cetak dengan mempertimbangkan narasi teks, bagian kosong dalam sebuah halaman, grafik, sistem penomoran yang jelas dan juga gambar.

\footnotetext{
محمود كامل الناقة. أسس إعداد مواد تعليم اللغة العربية وتأليفها في أللغة العربية إلى أين؟ 10

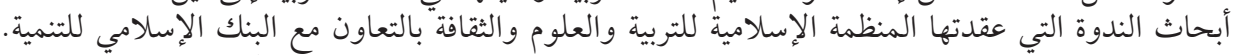

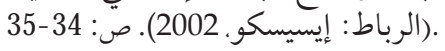


6) Ilustrasi

Ilustrasi ini juga berperan untuk membuat bahan ajar menjadi menarik melalui variasi penampilan. Ilustrasi digunakan untuk memperjelas pesan atau informasi yang disampaikan, selain itu juga membuat bahan ajar lebih komunikatif, memotivasi dan menarik siswa untuk membaca dan mempelajarinya.

7) Kelengkapan Dokumen

Paket bahan ajar memiliki tiga komponen inti, yaitu komponen utama, komponen pelengkap, dan komponen evaluasi hasil belajar. Komponen utama berisi informasi atau topik utama yang ingin disampaikan kepada peserta didik atau harus dikuasai. Komponen pelengkap terdiri atas informasi atau topik tambahan yang terintegrasi dengan bahan ajar utama, atau informasi atau topik pengayaan wawasan peserta didik. Sedangkan komponen evaluasi hasil belajar terdiri dari perangakat soal atau tes atau non tes untuk mengevaluasi hasil belajar siswa selama proses pembelajaran.

Masnur Muslich menambahkan beberapa poin penting dalam melakukan penyusunan bahan ajar, sebagaimana berikut:

1) Penentuan tujuan

Tujuan dalam pengembangan bahan ajar dibagi menjadi:

a) Tujuan Ranah Kognitif, sesuai dengan pendapat Bloom yaitu pengetahuan, pemahamanan, aplikasi, analisis, sintesis dan evaluasi. Ranah kognitif yang berkategori pemahan tergambar dalam kemampuan mahasiswa untuk memahami isi bahan ajar, yaitu mahasiswa membedakan, memperkirakan, menjelaskan, menguraikan lebih lanjut, merumuskan, dan meringkas materi. Ranah kognitif yang berkategori aplikasi, yaitu mahasiswa mampu menerapkan apa yang telah dipelajarinya dalam sebuah tindakan kongkrit. Seperti mahasiswa dapat menghasilkan, mendemostrasikan, memecahkan persoalan terhadap materi yang ia pelajari. Ranah kognitif yang berkategori analisis adalah kemampuan mahasiswa untuk menguraikan, mengidentifikasi, menghubungkan materi. Sedangkan ranah kognitif yang berkategori sintesis adalah kemampuan untuk menghubungkan bagian-bagian untuk membentuk suatu yang baru dengan menyimpulkan, menyusun dan mengkombinasikan materi yang 
telah dipelajari. Ranah kognitif yang berkategori evaluasi adalah kemampuan untuk mempertimbangkan nilai suatu bahan yang telah dipelajari dengan memberikan nilai, penafsiran, kritik sebuah materi dihubungkan dalam kehidupan nyata. Tujuan ini diarahkan pada penyikapan atau perasaan atas bahan yang telah dipelajarinya. Ranah afektif yang dimaksudkan berupa kemauan atau keberterimaan peserta didik dalam mengikuti kegiatan pembelajaran dalam bahan tertentu, baik secara individu maupun kelompok.

b) Tujuan Ranah Psikomotor

Tujuan yang berkaitan dengan keterampilan fisik terkait bahan yang telah dipelajari.

c) Tujuan Ranah Afektif

2) Pemilihan bahan

Dalam menentukan pemilihan bahan ajar, pengembang perlu memperhatikan hal-hal sebagai berikut:

a) Valid, yaitu materi yang dituangkan benar-benar teruji kebenaran dan keshahihannya. Materi yang diberikan adalah materi yang aktual dan memberikan konstribusi untuk pemahaman ke depan.

b) Tingkat kepentingan, yaitu materi yang dipilih benar-benar diperlukan siswa.

c) Kebermaknaan, materi yang dipilih dapat memberikan manfaat akademis yaitu memberikan dasar-dasar pengetahuan dan pemahaman yang akan dikembangkan lebih lanjut. sedangkan manfaat non akademis, yaitu dapat mengembangkan kecakapan hidup dan sikap yang dibutuhkan dalam kehidupan sehari- hari.

d) Layak dipelajari, yaitu materi yang dimaksud memungkinkan untuk dipelajari baik dari aspek tingkat kesulitan dan aspek pemanfaatan materi.

e) Menarik minat, materi yang dipilih dapat meningkatkan minat peserta didik untuk mempelajarinya lebih lanjut, menumbuh rasa keingintahuan sehingga memunculkan dorongan untuk mengembangkan kemampuan mereka. 
3) Pengumpulan bahan

Bahan adalah segala macam informasi yang terkait topik. Bahan ini didapatkan dari literatur-literatur baku, misalnya buku dan literatur pendukung seperti kumpulan makalah, majalah dan internet. Kesemua bahan dapat dimanfaatkan sebagai bahan ajar dengan syarat bahwa bahan harus relevan, aktual, objektif, dan tidak kontroversial.

4) Tahap pelaksanaan

Pembuatan bahan ajar dengan memperhatikan prinsip-prinsip pembuatan bahan ajar diatas dengan terlebih dahulu melakukan analisis kebutuhan peserta didik melalui komponen kurikulum, silabus dan tantangan pendidikan serta lingkungan dimana peserta didik berada. Semua ini saling berkaitan dan perlu diperhatikan bagi pengembang bahan ajar.

\section{Pembelajaran Maharah al-Qiraah Di Perguruan Tinggi}

Membaca dalam bahasa kedua bisa menggunakan bermacammacam jenis teks. Teks ini bisa diambil dari genre sastra seperti drama, cerita esai, puisi dan novel. Teks juga bisa berupa materi yang memberikan informasi tertentu (seperti label, resep masakan), materi yang ditujukan untuk memberikan orientasi (brosur biro perjalanan, menu restoran, daftar acara televisi dan jadwal keberangkatan pesawat, iklan), laporan yang bersifat evaluatif (seperti editorial, artikel majalah, esai, resensi) atau bisa berupa gambar visual diberi teks, seperti komik pendek yang dimuat di majalah atau koran. Pembaca dari berbagai teks ini perlu memahami secara eksplisif informasi yang disampaikan dalam teks. Sehingga Child (1987, dalam Ghazali) menyebutkan tentang keterampilan-keterampilan membaca sesuai dengan jenis teks dan membaca beragam teks diatas membutuhkan keterampilan membaca tertentu, seperti skimming dan scanning. ${ }^{11}$

Pembelajaran maharah al-Qiraah di perguruan tinggi bukan saja membekali agar mahasiswa dapat membaca teks-teks berbahasa Arab secara fashih dan sesuai kaidah gramatikal (nahwu sharaf), akan tetapi juga dapat memahami bacaan serta dapat mengambil inti sari dari pokok-pokok pikiran yang ada di dalam bacaan untuk diterapkan dalam kehidupannya.

11 A. Syukur Ghazali. Pembelajaran Keterampilan Berbahasa Dengan Pendekatan Komunikatif-Interaktif. (Bandung: PT. Refika Aditama). h: 206. 


\section{a. Tujuan Maharah al-Qiraah}

Tujuan umum dalam pembelajaran maharah al-Qiraah adalah untuk meningkatkan pemahaman membaca bagi pembelajar, seperti menghubungkan ide-ide bacaan dengan pengalaman yang dimiliki oleh peserta didik. Hal ini sangat bermanfaat untuk terus menumbuhkan pemikiran dan pengalamannya untuk selalu optimis. ${ }^{12}$

Tujuan khusus dalam pembelajaran maharah al-Qiraah untuk tingkatan lanjut adalah menumbuhkan kemampuan membaca pada tingkatan unsur pemahaman bacaan secara benar dan cepat dan pengetahuan kofnitif peserta didik akan membantunya untuk membedakan antara ide-ide pokok dan ide pendukung dan membaca kritis. ${ }^{13}$

Dalam hal membaca pemahan, para ahli bersepakat bahwa skemata pembaca menjadi penentu keberhasilan membaca pemahaman. Skemata adalah gambaran psikologis yang telah dimiliki pembaca ketika akan melakukan kegiatan baca. Skemata dapat berupa hasil pengalaman atau pengetahuan terdahulu yang dimiliki oleh pembaca. ${ }^{14}$ Sehingga seorang pembaca yang memiliki skemata yang baik, maka ia dapat mudah dalam memahami bacaan.

\section{b. Tahapan dalam pelajaran Maharah al-Qiraah}

Membaca adalah salah satu tujuan yang amat penting dalam program belajar bahasa-bahasa asing. Terkadang banyak kendala yang terjadi pada pembelajar bahasa asing di tingkat perguruan tinggi dalam pelajaran al-Qiraah, yaitu pada fase pra baca, saat baca dan juga pasca baca, hal ini disebabkan kurang adanya kesiapan bagi mahasiswa sebelum masuk kelas, walaupun pendidik telah berulang kali memberikan semangat dan motivasi kepada mereka. ${ }^{15}$

Menurut Gray (dalam Habibullah) ada tiga tahapan dalam membaca yaitu membaca teks, dalam teks dan dibalik teks. Dan ada yang berpendapat

\footnotetext{
محمود فندي العبد الله. أسس تعليم القراءة الناقدة للطلبة المتفوقين عقليا. (عمان: عالم الكتب الحديث، 12 2007). ص: 85. 
membaca terdiri atas tahapan huruf(المستوى الحرفي) pemahaman (المستوى) التفسيري) dan praktek (المستوى التطبيقي). ${ }^{16}$ Membaca tahapan huruf adalah untuk mengetahui apa yang tertulis dalam teks, tahapan pemahaman untuk memahami, menafsirkan, menjelaskan atau menganalisis teks, sedangkan Membaca praktek adalah membaca kritis dengan memberikan pendapat atau solusi seputar masalah yang ada dalam kehidupan pembaca.

Sedangkan Hardly (2001) dalam Abidin ${ }^{17}$ menyebutkan prosedur pembelajaran membaca meliputi beberapa tahapan sebagai berikut:

1) Tahap prabaca, yakni tahapan yang dilakukan peserta didik sebelum membaca yang berupa curah pendapat tentang ide umum dalam teks, mempelajari berbagai visualisasi dalam teks dan prediksi tentang teks.

2) Tahap baca, yakni tahapan inti kegiatan pembelajaran membaca. Pada tahap ini dilakukan serangkaian prosedur yaitu

a) Tahap membaca skimming dan scaning untuk menemukan inti sari bacaan mengidentifikasi ide pokok dan penunjang, , memilih uraian terpenting yang terkandung dalam bacaan, mengisi format isi bacaan, mencocokkan subjudul dengan paragraf isi, mengisi format si bacaan dengan kata-kata kunci, dan membuat tanggapan umum atas isi bacaan.

b) Tahap membaca teks secara intensif

c) Tahap pemahaman.

3) Tahap pasca baca, yakni tahap akhir yang dilakukan untuk membuktikan pemahamannya atas kegiatan membaca. Tahap ini bisa diakukan melalui kegiatan integrasi membaca dengan keterampilan berbahasa yang lain, misalnya merangkum dan menceritakan kembali isi bacaan secara lisan.

محمد حبيب الله. أسس القراءة وفهم المقروء بين النظرية والتطبيق. (عمان: دار عمار، 2000). 6 17 Yunus Abidin. h: 65. 


\section{Pengembangan Bahan Ajar Maharah Al-Qiraah I Berbasis Pendidikan Karakter di Jurusan Bahasa dan Sastra Arab Fakultas Humaniora UIN Maulana Malik Ibrahim Malang}

Adapun contoh pengembangan bahan ajar Maharah al-Qiraah I berbasis karakter yang telah penulis kembangkan dengan mengikuti berbagai tahapan yang dilalui dalam proses pengembangan bahan ajar adalah sebagai berikut:

a. Sesuai dengan KKNI Jurusan Bahasa dan Sastra Arab, Matakuliah maharah al-Qiraah I dipasarkan pada mahasiswa semester II jurusan Bahasa dan Sastra. Tujuan dari matakuliah ini adalah: Mahasiswa dapat membaca beraneka ragam teks yang terdiri dari Teks pendidikan, Agama, Bahasa, Sastra, Sosial, dan Kepahlawanan dengan baik dan benar sesuai dengan gramatikal (nahwu sharaf).

b. Bahan-bahan dalam rangka penyusunan materi ini menggunakan berbagai teks yang diambil dari buku, kumpulan makalah, majalah dan internet dengan mempertimbangkan prinsip-prinsip dalam mengembangkan bahan ajar, yaitu isi, keterbacaan bahan ajar dan keluasan bahan ajar. Adapun rincian topik yang diberikan tertulis dalam Rencana Pembelajaran Semester yaitu:

\begin{tabular}{|c|c|c|}
\hline No & Pertemuan & Judul Bacaan \\
\hline 1. & 1 & Kontrak perkuliahan dan pengenalan matakuliah \\
\hline 2. & $2-3$ & النص التربوي: الصفات الأساسية للمربي \\
\hline 3. & $4-5$ & النص الديني: عشر صفات لبناء شخصية المسلم \\
\hline 4. & $6-7$ & النص اللغوي: خصائص اللغة العربية \\
\hline 5. & 8 & UTS \\
\hline 6. & 9 & النص الأدبي: الأسد الجائع \\
\hline 7. & $10-11$ & النص الإجتماعي: مشكلات الشباب في المجتمع \\
\hline 8. & $12-13$ & النص الطبي: الأدوية في العرب \\
\hline
\end{tabular}




\begin{tabular}{|c|c|c|}
\hline 9. & $14-15$ & النص البطولي: السيرة النبوية \\
\hline 10. & 16 & UAS \\
\hline
\end{tabular}

Pada materi 10. مشكلات الشباب في الجُتمع teks ini berisikan tentang problemantika pemuda dalam masyarakat.

Kompetensi yang diinginkan: mampu membaca teks al-Ijtima'i secara baik dan benar sesuai dengan gramatikal (nahwu, sharaf).

Materi:

$$
\text { مشكلات الشباب في المجتمع }
$$

الصفات الأساسية للمربي القيام بالعمل التربوي هو من أعظم الأعمال التي تنتظرها الأمة من أبنائها الدعاة

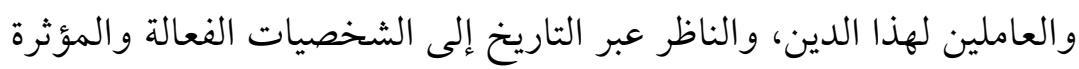

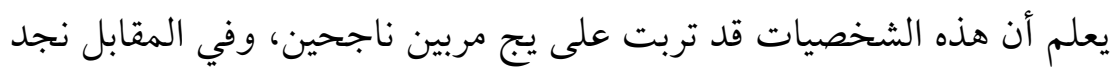

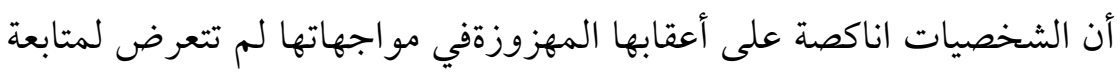
تربوية ناجحة-هذا في الأعلب وهو الذي يحكم عليه. ويدقعنا كل ذلك إلى إلى

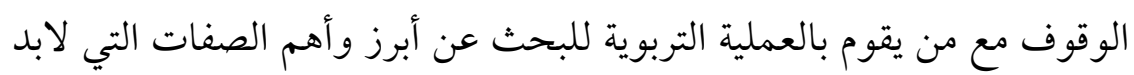

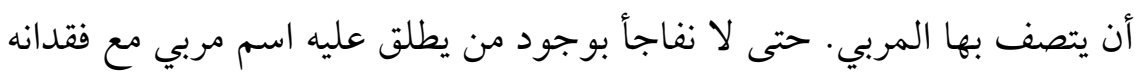

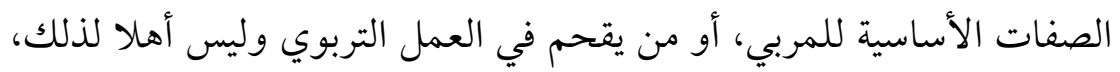

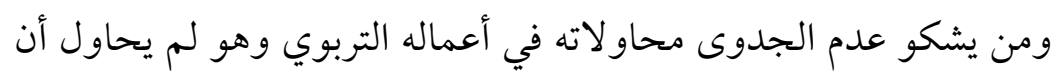

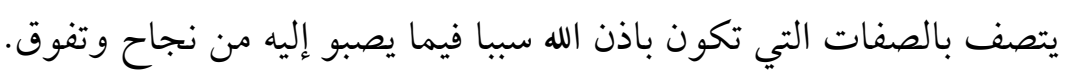
ونأتي الآن إلى الصفات الأساسية للمربي: العلم: ويذكر الشيخ محمد الدريش أن هذه الصفة هي أول الصفات العلم

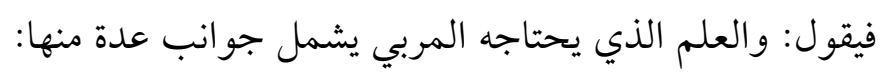

العلم الشرعي: فالتربية في الإسلام إعداد للمرء للعبودية لله تبارك وتعالى وذلك لا يعرف إلا بالعلم الشرعي. والعلم الشرعي يعطي المرء الوسيلة للإقناع 


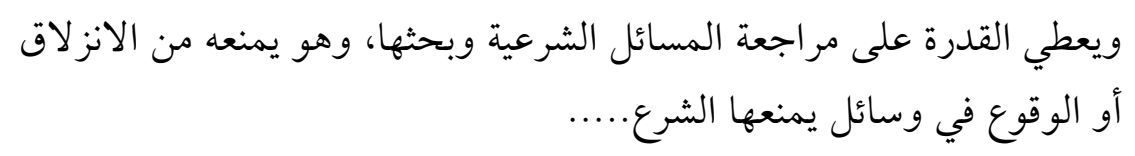

Latihan-latihan dalam materi ini adalah:

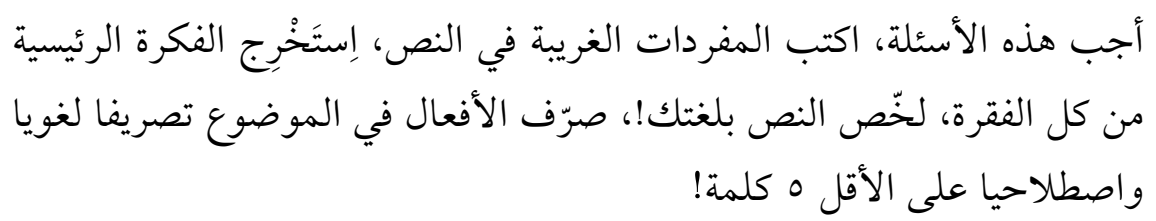

Dari paparan diatas, pemilihan topik sangat penting, sebab dapat mengarahkan mahasiswa untuk mengapresiasi nilai-nilai karakter yang terkandung dalam teks tersebut.

\section{Simpulan}

Pendidikan karakter bertujuan untuk menginternalisasikan nilainilai karakter melalui berbagai media, diantaranya melalui bahan ajar. Pembelajaran maharah al-Qiraah berbasis karakter adalah salah satu usaha pendidik untuk berupaya memberikan muatan-muatan pendidikan karakter di perguruan tinggi untuk menjadikan peserta didik atau mahasiswa yang berkarakter.

\section{DAFTAR PUSTAKA}

Abidin, Yunus. Pembelajaran Membaca Berbasis Pendidikan Karakter. (Bandung: PT. Refika Aditma, 2012).

Belawati, Tian. Pengembangan Bahan Ajar. (Jakarta: Pusat Penerbitan Universitas Terbuka, 20013).

Ghazali, A. Syukur Pembelajaran Keterampilan Berbahasa Dengan Pendekatan Komunikatif-Interaktif. (Bandung: PT. Refika Aditama).

Hermawan, Acep. Metodologi Pembelajaran bahasa Arab. (Bandung: PT. Remaja Rosdakarya. 2011).

Muhaimin Azzet, Akhmad. Urgensi Pendidikan Karakter Di Indonesia. Jogjakarta: Ar-Ruzz Media, 2011).

Muslich, Masnur. Text Book Writing: Dasar-dasar Pemahaman,Penulisan dan Pemakaian Buku Teks. (Jogjakarta:Ar-Ruzz Media). 
Ratna, Nyoman Kutha. Peranan Karya Sastra, Seni dan Budaya Dalam Pendidikan Karakter. Yogyakarta: Pustaka Pelajar. 2014). H: 74. Wibowo, Agus. Pendidikan Karakter Berbasis Sastra. (Yogyakarta: Pustaka Pelajar, 2013).

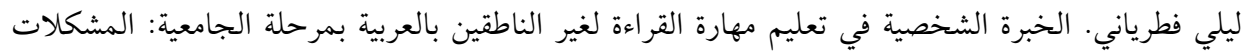

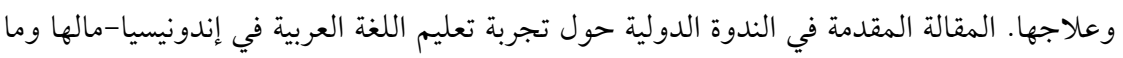

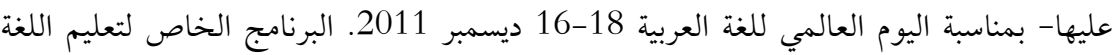

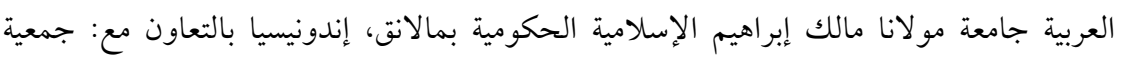

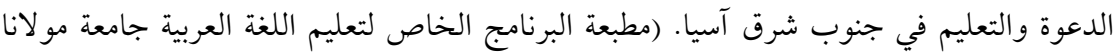
مالك إبراهيم الإسلامية الحكومية بمالانق: 2011). محمد حبيب الله. أسس القراءة وفهم المقروء بين النظرية والتطبيق. (عمان: دار عمار، 2000).

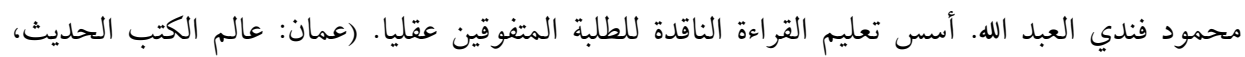
(2007

محمود كامل الناقة. أسس إعداد مواد تعليم اللغة العربية وتأليفها في أللغة العربية إلى أين؟ أبحاث الندوة التي

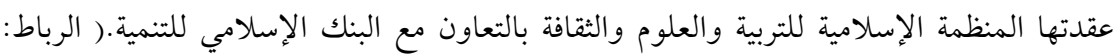

$$
\text { إيسيسكو، 2002). }
$$

علي الحديدي. مشكلات تعليم اللغة العربية لغير العرب. (القاهرة: دار الكاتب العربي، 1966) 